\title{
MOSAICOS, REFLEXOS E TRANSITIVIDADES DA HISTÓRIA DA PEDAGOGIA E DA FORMAÇÃO DOCENTE NO BRASIL
}

Mosaics, reflections and transitivities in the history of Pedagogy and teaching training in Brazil

Mosaicos, reflexiones y transitividades en la historia de la Pedagogía y la formación docente en Brasil

Received: august $/ 2020$

Accepted: september $/ 2020$

Available online: september/2020

Caio Corrêa Derossi; Licenciado em História pela Universidade Federal de Viçosa (UFV).

Mestrando pelo Programa de Pós-Graduação em Educação pela mesma instituição; E-mail: derossi.caio@gmail.com

Thaís Carneiro Carvaho; Licenciada em Pedagogia pela Universidade Federal de Viçosa (UFV).

Mestranda pelo Programa de Pós-Graduação em Educação pela mesma instituição; E-mail: thaiscarvalho471@gmail.com

Karen Laíssa Marcilio Ferreira; Licenciada em Pedagogia pela Faculdade Capixaba da Serra, MULTIVIX. Mestranda pelo Programa de Pós-Graduação em Educação pela Universidade Federal de Viçosa; E-mail:karenkaispa@gmail.com

Karla Helena Ladeira Fonseca;Licenciada em Pedagogia pela Universidade Federal de Viçosa (UFV). Mestranda pelo Programa de Pós-Graduação em Educação pela mesma instituição; E-mail: karlaladeira1@gmail.com 
Ana Paula Machado Gomes; Licenciada em Educação Infantil pela Universidade Federal de Viçosa (UFV). Mestranda pelo Programa de Pós-Graduação em Educação pela mesma instituição; E-mail: anapaula.1.apm2@gmail.com

Resumo: O presente ensaio teórico de abordagem qualitativa e naturezas bibliográfica e documental, propõe a partir de uma análise histórica em longa duração, do fim do período imperial, nos ritos do século XIX até a primeira década do século XXI, compreender os processos sociais, políticos, econômicos e históricos que permearam a constituição do campo da formação de professores, com especial atenção para a Pedagogia. Nesse sentido, a partir dos estudos da literatura especializada e de documentos legais que versavam sobre o histórico da formação de professores, sobre o curso de Pedagogia e os parâmetros formativos, discutiu-se os percursos históricos do desenvolvimento profissional do pedagogo, considerando as interfaces entre os desafios e os limites de suas formações, frente aos contextos profissionais específicos da sua atuação. Ao fim, aponta-se para a necessidade de se repensar o curso de Pedagogia, observando o compromisso social da profissão e a primazia da formação humana perante a outros interesses.

Palavras-chave: História da educação, História da formação de professores, História do curso de Pedagogia.

\begin{abstract}
The present theoretical essay with a qualitative approach and bibliographic and documentary nature, proposes, based on a long-term historical analysis, from the end of the imperial period, in the rites of the 19th century to the first decade of the 21 st century, to understand the social, political, economic and historical factors that permeated the constitution of the field of teacher education, with special attention to Pedagogy. In this sense, from the studies of specialized literature and legal documents that dealt with the history of teacher education, the Pedagogy course and the formative parameters, the historical paths of the pedagogical professional development were discussed, considering the interfaces between the challenges and limits of their training, given the specific professional contexts of their work. In the end, it is pointed out the need to rethink the Pedagogy course, observing the social commitment of the profession and the primacy of human formation before other interests.
\end{abstract}

Keywords: History of education, History of teacher education, History of the Pedagogy course.

Resumen: El presente ensayo teórico con enfoque cualitativo y de carácter bibliográfico y documental, propone, a partir de un análisis histórico de largo plazo, desde el final del período imperial, en los ritos del siglo XIX hasta la primera década del siglo XXI, para comprender lo social, político, Factores económicos e históricos que impregnaron la constitución del campo de la formación del profesorado, con especial atención a la Pedagogía. En este sentido, a partir de los estudios de literatura especializada y documentos legales que abordaron la historia de la formación docente, el curso de Pedagogía y los parámetros formativos, se discutieron los caminos históricos del desarrollo profesional pedagógico, considerando las interfaces entre los retos y límites de su formación, dados los contextos profesionales específicos de su trabajo. Al final, se señala la necesidad de repensar el curso de Pedagogía, observando el compromiso social de la profesión y la primacía de la formación humana antes que otros intereses.

Palabras clave: Historia de la educación, Historia de la formación del profesorado, Historia del curso de la Pedagogía.

\title{
INTRODUÇÃO
}


A Pedagogia só alcançou o reconhecimento enquanto campo de produção de conhecimento ${ }^{1}$ no Brasil apenas no século XX, embora viesse de longa data a trajetória da área. Mesmo com a independência conseguida em termos científicos, socialmente o campo pedagógico continuou a ser pensado em segunda escala, preterida em relação a outros setores, reverberando até na literatura, uma representação que a Pedagogia era restrita as moças que sonhavam em se casar e buscar, mesmo que de forma reduzida, uma ascensão social, a exemplo do livro A Normalista, de Adolfo Caminha, lançado originalmente ao final do século XIX. ${ }^{2}$ Em razão da constituição do campo de estudos e das relações sociais, as políticas públicas, os processos de ensino-aprendizagem e os entendimentos acerca da formação de professores serão os maiores prejudicados, em função da ausência ou insuficiência com relação a articulação e a efetivação de tais elementos, que em certa medida, são sentidos até os presentes dias ecos da desigualdade e de outros problemas sociais históricos. Portanto, refletir sobre tais questões nos impele a compreender e a analisar a partir de uma mirada histórica e panorâmica as (des)continuidades de um processo dinâmico, por vezes antagônico e interseccionado por conjunturas sociais, políticas e econômicas.

Dessa forma, o presente ensaio teórico, assentado na discussão com a literatura científica especializada, de natureza qualitativa, busca refletir historicamente sobre o processo de formação de

\footnotetext{
${ }^{1}$ Entende-se na perspectiva do sociólogo francês Pierre Bourdieu, que descreveu campo como espaços sociais de lutas e de disputas em torno de um objeto específico que geram as especificidades das áreas de conhecimento. Entretanto, o autor aponta para a existência de leis gerais que tratam do funcionamento e da estrutura que perpassa os distintos campos. Tal estrutura refere-se a dinâmica das lutas empregadas pelas instituições e sujeitos, no que diz respeito aos capitais acumulados e as estratégias para as disputas (BOURDIEU, 1983b). Para o autor, a produção de conhecimento científico, nas diversas áreas, atribuem particularidades internas ao campo, a partir de leis gerais as quais todos estão submetidos. Assim, cada campo investe de forma particular forças em prol de seus interesses (BOURDIEU, 1983a). Portanto, a partir de uniões ou distinções, os campos se estruturam para a detenção de determinado capital. Cada campo tem uma estrutura hierárquica que denota como os sujeitos vão se relacionar com o capital em questão. O capital simbólico é o circulante no campo de produção cultural e retrata as instituições ou agentes, que no decorrer das disputas internas do campo, acumularam a chancela, o respaldo, a institucionalização, o reconhecimento de fala conseguida ou não pelos interlocutores em questão (BOURDIEU, 1990). Imbuídos desses sentidos, entende-se a formação de professores e a história da educação como campos, já que elas são permeadas por disputadas e interesses vários durante o tempo.

${ }^{2}$ A obra A Normalista, do escritor cearense Adolfo Caminha, pertence a Escola Literária Naturalista, do final do século XIX. O enredo principal narra a história de Maria do Carmo, moça pobre do interior que é criada pelos padrinhos de classe média na zona urbana para que pudesse ter a oportunidade de estudar. Entre outras nuances, a obra oferece traços e reflexos sobre a escolarização confessional, sobre as Escolas Normais e sobre os demais elementos que se referem as alunas, os entendimentos acerca da educação e da estruturação social do período.
} 
professores no Brasil, com enfoque no trabalho do pedagogo ${ }^{3}$. Todo o recorte é concomitante com os marcos e regulamentações do Estado, evidenciando como período temporal o século XIX, após a independência, quando é desenhado e traçado a configuração do Estado Nacional e por conseguinte, do país. A escolha do recorte temporal é de longa duração, por se acreditar na análise integral e ampliada dos objetos evidenciados. Cabe destacar que o presente texto não refletirá sobre o período colonial, pelas motivações de adequação da compreensão pretendida e por entender que na colônia, a instrução, a educação não eram alvos de ações contínuas e permanentes da Coroa Portuguesa, sendo exercida e vinculada na maior parte do tempo junto às ordens religiosas, dentro das principais delas, a jesuítica. ${ }^{4}$ Assim, o artigo versará sobre cinco períodos históricos para a composição das teias de relação e sentido, sendo eles: o do Império que marca a educação como uma das formas de instituir uma ordenação de viés moral e social para a população; a constituição das Escolas Normais posterior à proclamação da república; o processo de modernização dos anos de 1930 e a criação do curso de Pedagogia; o fechamento das Escolas Normais e a formação tecnicista e fragmentada preconizada durante a ditadura civil-militar e a crítica a formação pedagógica realizada no período de redemocratização, juntamente com o avanço neoliberal principalmente nas políticas públicas que tratam dos direitos sociais, vivenciado na década de 1990.

\section{DESENVOLVIMENTO}

Durante o século XIX, principalmente após o processo da independência ocorrida em 1822, o Brasil inicia uma dinâmica para a formação da nação e do Estado. Apesar de todas as intenções de se construir uma história oficial que revelasse nuances contínuas em prol da constituição de uma memória coletiva, é sabido que fora dinâmico e antagônico o percorrer da instauração do Estado e

\footnotetext{
${ }^{3}$ Para facilitar a leitura e a escrita do artigo e considerando a alta recorrência durante o texto, onde se lê "pedagogo(s)" e "professor(es)", entende-se pedagogos e pedagogas, professores e professoras.

${ }^{4}$ Para os interessados nas discussões acerca da História da Educação no período Colonial, sugere-se a leitura, entre outras, dos trabalhos dos professores e das professoras Thaís Nívia de Lima Fonseca, Álvaro de Araújo Antunes, Ana Cristina Pereira Lage, Christianni Cardoso Moraes, Sílvia Maria Amâncio Rachi Vartuli e José Newton Coelho Meneses.
} 
da nação. Saviani (2012) entende que nesse período, os debates educacionais estarão associados as dimensões da memória e da cultura. A Constituição de 1824 já continha um direcionamento sobre a sistematização do ensino no país. Entretanto, em função do enfoque em outras questões e na dificuldade de se efetivar as diretrizes que insistiam em ficar nas letras frias da lei, a educação passa a ser uma obrigação das províncias, sendo o governo central desobrigado a financiar e construir um currículo e um sistema educativo. Esse quadro era ilustrativo da ausência e da insuficiência da educação brasileira no período, além de escancarar as diferenças sociais: enquanto a maioria da população estava afastada dos bancos escolares e era composta por uma massa de analfabetos miseráveis, a incipiente elite enviava seus filhos às universidades europeias e/ou propiciava a educação particular ou confessional, em âmbito doméstico com tutores estrangeiros.

Os percursos escolares no Império foram poucos e sem respaldos pedagógico e científico, no sentido de um enfoque em leitura e operações matemáticas básicas, que não oportunizariam uma autonomia, independência ou reconhecimento social a partir da alfabetização. Para Saviani (2012) a estruturação do espaço escolar se assemelhava ao do espaço doméstico, que se realizava em um único ciclo. Também segundo o autor, era concomitante a presença do método do ensino mútuo ou de Lancaster, no qual o professor instruía alunos mais velhos e preparados para atuarem como uma espécie de monitores para os alunos mais novos ou recém-ingressantes. Nesse sentido, levando em consideração os aspectos sociais, políticos, econômicos, do trabalho e da formação docente, o que estava em jogo era um repetição, uma reprodução de uma ação e não a premissa de adequação teórico-pedagógica ou da expansão do ensino com qualidade. Assim, mesmo com entendimento que o professor devesse ser formado, a Pedagogia continuava secundarizada, mesmo com a criação das primeiras Escolas Normais, de modelo europeu, fundadas nos anos de 1830. Saviani (2012, p. 13) afirma que

[...] predominou nelas a preocupação com o domínio dos conhecimentos a serem transmitidos nas escolas de primeiras letras. Nesse sentido, pode-se considerar que gravitavam, ainda, em torno do modelo dos conteúdos culturais-cognitivos. O currículo dessas escolas era constituído pelas mesmas matérias que integravam o currículo das 
escolas de primeiras letras. Portanto, o que se pressupunha era que os professores deveriam ter o domínio daqueles conteúdos que lhe caberia transmitir às crianças, excluindo-se, ou pelo menos secundarizando, o preparo didático-pedagógico sob forma intencional e sistemática.

Tal configuração institucional foi instável até a década de 1870, em razão das críticas ao modelo adotado e ao par custo versus eficiência. Saviani (2008, p. 13) sublinha que os ataques às Escolas Normais revelavam também a concorrência com o modelo de formação de professores adjuntos que “[...] atuariam nas escolas como ajudantes do regente de classe, aperfeiçoando-se nas matérias e práticas de ensino". Logo, é percebido um conflito de intenções e de interesses internos as obrigações ou não do próprio Estado, já que o entendimento formativo dos professores adjuntos ausentava de responsabilidade o governo em formar novos professores. Reverberando na diminuição da criação de novas Escolas Normais e no interesse do próprio indivíduo em seguir pelo magistério, uma vez que a área era associada ao dom, à vocação e ao quase sacerdócio. Portanto, quando comparado a outros países, respeitando as idiossincrasias históricas e formativas, o Brasil do século XIX, estava à beira da falésia em relação a países como Argentina, França e Estados Unidos, que calcados em um projeto de base iluminista, ampliaram a escolarização pública. Mesmo não sendo partidário de uma busca de origens e gêneses para problemas estruturais e históricos, o quadro em alguns pontos deficitário da educação brasileira, pode ser pensado frente a tais cenários.

Embora os problemas e a falta de efetivação em políticas para a educação, não se pode desconsiderar os esforços e os debates públicos, veiculados em jornais e em revistas, principalmente com a assunção do jovem imperador Dom Pedro II, em um contexto de término do período regencial e de controle de revoltas e movimentos sociais regionais que lutavam pela independência de tais localidades do Brasil. Narita (2019, p. 107) destaca que

Os anos 1850 sinalizam, para além das viradas nas pautas políticas e econômicas, uma nova auto compreensão do Império a partir da construção, junto ao debate público/político, de uma significativa esfera para preocupações com processos educativos como condições de reprodução da dinâmica social.

Entende-se, portanto, que junto da ordenação imperial, abriu-se uma série de projetos sociais preocupados com a formação do povo, das identidades e das memórias, a partir de interesses e 
entendimentos políticos, que perfizeram durante o tempo. De forma ampliada, tais projetos se alinhavam as discussões de ordem econômica que apontavam para os processos crescentes de industrialização e de comércio. Nessa direção, Narita (2019, p. 113) dispõe que:

Como aperfeiçoamento moral e material, os processos de educação e a atenção à infância configuravam práticas de uma vida urbana, tornando tangível os próprios giros modernizadores no Império, nos anos 1850, com a estruturação de um capitalismo comercial e as atividades urbanas.

Com tal cenário, duas questões se agigantam em relação a dinâmica educacional: a preparação da população e da formação de mão-de-obra para a vigência de uma ordem social nova, adequada e articulada as dinâmicas e transformações do sistema capitalista. Logo, é percebido uma mudança das classes sociais no Brasil, em razão do alinhamento, mesmo que periférico, com a ideia modernizante do capitalismo estrangeiro, que preconizava as relações de classe a partir das ordens moral e sociopolítica pré-determinadas. Portanto, para Narita (2019, p. 123)

A própria educação da infância significava um esforço sobre a gênese das ações e dos costumes, estruturando uma completa interdependência entre o indivíduo e a coletividade ao tomar como referência uma pauta de valores em que as ações e as intenções nelas depositadas classificam e expõem as assimetrias da esfera social.

A criança era preparada para conviver no espaço público conforme as indicações sociais prescritas na época, sendo os entendimentos morais os mais preconizados, fazendo com que a educação fosse também responsável por interiorizar as formas adequadas e corretas de se viver em sociedade. Nesse sentido, além do Estado, a sociedade civil também se interessava e demonstrava atenção com a formação do povo e da criança, a partir de um itinerário moralizante, requisito fundamental da modernidade, segundo Narita (2019). Tendo em vista o quadro social e as demandas educativas preconizadas, o processo de formação de professores só vai sentir diferenças mais significativas com o fim do Império e início da República, nos últimos anos do século XIX. Mesmo a República não colocando em seu horizonte o estabelecimento de um sistema escolar como destino principal, é nesse período que ocorrem uma série de reformas estaduais na educação, 
impactando a organização escolar e a configuração das Escolas Normais, temas que serão tratados a seguir.

Os diferentes estados brasileiros encaminharam reformas educacionais no período republicano, haja vista que historicamente o governo central não se responsabilizava com a gestão, com o financiamento e com a efetivação dos sistemas educativos. Tais reformas vão impactar no funcionamento e nas concepções da educação, como um todo, bem como das instituições que ofereciam o curso normal. Em razão de um recorte e de uma opção para a produção do presente artigo, será retomado o caso específico do estado de São Paulo, com exemplos e análises. As mudanças na instrução pública paulista começaram no ano de 1890. Existia uma insatisfação com o funcionamento das Escolas Normais, fomentando a criação de um plano que versasse sobre a formação de professores. Nessa direção, Saviani (2012, p. 15) afirma que:

A reforma foi marcada por dois vetores: enriquecimento dos conteúdos curriculares anteriores; e ênfase nos exercícios práticos de ensino, cuja marca característica foi a criação da Escola-Modelo anexa à Escola Normal, na verdade a principal inovação da reforma. De fato, foi por meio dessa escola de aplicação que o modelo pedagógico-didático se tornou a referência para a formação de professores propiciada pelas Escolas Normais.

A reforma paulista propõe que os elementos de conhecimentos disciplinar, pedagógico, cultural e prático sejam entendidos de forma conjunta, uma vez que a formação dos professores dependia da articulação desses eixos. Nessa perspectiva também, o governo estadual assume um protagonismo por ser ele o responsável pela condução, formatação e concepção das escolas, dos sistemas educativos e do tipo de professor que se formará. As ações do governo foram exitosas em algumas dimensões e foram se espalhando a nível municipal nas diferentes regiões do estado. A tônica das reformas se baseava na junção de aspectos práticos com os disciplinares, propondo assim, a formação de um outro profissional. Ademais, Saviani (2010, p. 15) retrata que apesar de não ter sido efetivada, "Foi também nessa reforma da instrução pública paulista do início da República que ocorreu a primeira tentativa de elevar os estudos de educação ao nível superior”. Somente após a crise econômica decorrente da quebra da Bolsa de Nova Iorque, nos Estados 
Unidos em 1929 que ocorrerá a sistematização e o contexto favorável de abertura para a apropriação do ensino superior, sendo o Decreto $n^{\circ} 19.851$ de 1931 que institui o Estatuto das Universidades Brasileiras, versará segundo Saviani (2012) na constituição das Instituições de Ensino Superior no país. Embora as universidades não prescindissem da existência de Faculdades de Filosofia, Letras, Ciências Humanas e Artes, visto que elas também não tinham o prestígio e o reconhecimento social das tradicionais instituições de Direito, de Engenharias e de Medicina, inseridas no projeto de modernização do país, o que estava posto era a preponderância de se pensar a formação docente para o desenvolvimento em múltiplos aspectos do Brasil.

É no sentido da busca pela modernização que o Estado, assumindo uma posição mais centralizadora em 1930, vai assumir toda a regulação e a estruturação dos assuntos educacionais, em esfera nacional. Assim, políticos como Francisco Campos, responsável pelo Estatuto das Universidades vai propor a criação de Faculdades de Educação, Ciências e Letras para combater o quadro da educação empobrecida e melhorar o nível de conhecimento dos alunos, como sublinha Saviani (2012). O problema que se coloca é que a proposta de criação de tais faculdades assume um viés utilitarista para a formação, baseado na transmissão e na projeção de determinados conhecimentos, considerados relevantes para o ensino, sem observar a história pregressa, o contexto de atuação e os saberes já existentes desses professores. E a tais docentes caberia a tarefa de reconstruir toda base cultural da população, a alinhando a modernização e a industrialização crescentes, que eram as principais nuances da política externa e do contexto socioeconômico paralelo as perspectivas internacionais.

A educação então serviria aos interesses do Estado, compondo o projeto nacional moderno, para a formação de cidadãos preparados para as novas demandas sociais e econômicas. Nessa direção, são criadas as Universidade do Distrito Federal (UDF) ${ }^{5}$ e a Universidade de São Paulo

\footnotetext{
${ }^{5}$ A Universidade do Distrito Federal (UDF) foi criada em 1935, período que a cidade do Rio de Janeiro era a capital do país. Idealizada por Anísio Teixeira, secretário de Educação na época, além de sediar cursos considerados tradicionais, tais como: Direito, Engenharias e Medicina, contava com uma Faculdade de Educação, marcando uma formação específica para o magistério, em nível superior. Entretanto, durante o período do Estado Novo Varguista, em 1939, a
} 
(USP), localizadas em centros políticos de destaque: a primeira no Rio de Janeiro, capital do país e a segunda na cidade homônima ao nome da instituição. As universidades vão também representar um passo para a formação docente aliada aos preceitos de renovação presente desde os anos de 1920 e que ganharam fôlego com o Movimento da Escola Nova no governo Varguista. Porém, é importante destacar que a maioria dos princípios defendidos pelos teóricos escolanovistas, tais como: a autonomia, a laicidade, a descentralização e a democracia foram lidos como ideais comunistas, gerando ataques a pessoas e a instituições, como o exemplo de Anísio Teixeira e da UDF, como denota Saviani (2012). Nessa mesma direção, com o estreitamento de direitos e maior centralização do Estado, no período mais autoritário do governo Vargas, o Estado Novo (1937-1945), o entendimento restrito e utilitário da formação de professores e da função da universidade voltou a imperar, sendo a Universidade do Brasil, nomenclatura nova para antiga UDF, instaurada pelo ministro da Educação e da Saúde Pública Gustavo Capanema, o modelo que deveria ser seguido por todo o Brasil a partir de 1937. Assim, Saviani (2012, p. 33) evidencia que foi “[...] a Universidade do Brasil, de fato, [que] determinou a forma de organização desse nível de ensino durante todo o período que vai de 1940 a 1968". É em tal contexto que é elaborado o primeiro curso superior de Pedagogia no país.

Constituído na Faculdade Nacional de Filosofia (FNFi) da Universidade do Brasil e regimentado pelo Decreto-Lei $\mathrm{n}^{\mathrm{o}} 1.190$ de 1939, o primeiro curso de Pedagogia foi criado, já estabelecendo certa influência dentro do território nacional e servindo como modelo curricular para os demais. Segundo Tanuri (2000, p. 74) o curso visava “[...] à dupla função de formar bacharéis, para atuar como técnicos de educação, e licenciados, destinados à docência nos cursos normais". As questões próprias do nascimento do curso, como a destinação e a titulação da formação oferecida se revelou problemática e pode ser indiciosa para se refletir a formação pedagógica atualmente e a atuação do professor na educação básica. Para Silva (1999, p. 34) "Em sua própria gênese o curso

UDF foi fechada e deslocada a estrutura e o pessoal para a Universidade do Brasil.

RBPPD/BRJPD | Vol. 2 | n. 3 | p. 1-34, 2020. 
de Pedagogia já revela muito dos problemas que o acompanham ao longo do tempo. Criou um bacharel em Pedagogia sem apresentar elementos que pudessem auxiliar na caracterização desse novo profissional". O currículo denota uma inadequação na formação pedagógica, já que o curso que propunha duas habilitações, sem pensar nas distintas inserções profissionais e identitárias, bem como no parco relacionamento entre as disciplinas, que ainda concebia a separação de matérias culturais e específicas das didático-pedagógicas. Para Saviani (2012, p. 35) a questão das modalidades licenciatura e bacharelado necessitam ser compreendidas no contexto de sua inserção, já que:

\begin{abstract}
Todos os cursos da Faculdade Nacional de Filosofia e, dado o seu caráter de modelo padrão, também das demais faculdades de filosofia, ciências e letras instaladas no país, organizaram-se em duas modalidades: o bacharelado, com a duração de três anos, e a licenciatura. O curso de pedagogia foi definido como um curso de bacharelado ao lado de todos os outros cursos das demais seções da faculdade. O diploma de licenciado seria obtido por meio do curso de didática, com a duração de um ano, acrescentado ao curso de bacharelado. Está aí a origem do famoso esquema conhecido como " $3+1$ ".
\end{abstract}

Não se pode conceber formação de professores quando não se tem o diálogo entre as disciplinas de conteúdos específicas com as próprias da profissão docente, que são as didático-pedagógicas. Corroborando com o quadro de incongruências formativas, as discussões acerca dos problemas da realidade brasileira não compunham as disciplinas e ocorreu a dispensa das escolas-laboratório. Então, mais problemas se instalam: como buscar a qualificação e a profissionalização dos docentes, quando se mina o processo de ensino e aprendizagem e se investe na separação dicotômica entre teoria e prática? Como potencializar o nível cultural da população brasileira, como defendia o governo, formando mal os professores? Tendo em vista essas e outras questões, pode-se repensar se de fato a formação preconizada pelo governo não se enfatizava apenas em uma lógica discursiva e não em uma forma mais efetiva ou as medidas eram propositais para uma formação de docentes e discentes precárias? De certo, não se pode propor a profissionalização dos professores sem uma interface de reflexão sobre as aprendizagens e sobre as práticas. Não é recomendável apostar em uma dicotomia, em um antagonismo entre os aspectos teóricos e práticos da formação docente, pois ambos os aspectos contribuem com a avaliação, 
compreensão, análise e condução de desafios e limites presentes no exercício profissional e formativo dos sujeitos. Logo, Saviani (2009, p. 147) retrata que “[...] o aspecto pedagógico-didático, em lugar de se constituir em um novo modelo a impregnar todo o processo da formação docente, foi incorporado sob a égide do modelo dos conteúdos culturais-cognitivos”.

Além disso, é interessante pensar no espaço de atuação profissional do pedagogo, que era outra questão que se colocava como um desafio, uma vez que a formação era dividida entre bacharel e licenciado, refletir sobre a colocação profissional assume um relevo, já que pressupõe atividades e funções distintas a depender da modalidade formativa. Para Silva (1999, p. 35) a incongruência da separação entre as formações e a inserção profissional se inicia “[...] pela expectativa do exercício de funções de natureza técnica a serem realizadas por esse Bacharel e, de outro, pelo caráter exclusivamente generalista das disciplinas fixadas para sua formação”. Uma das implicações da indefinição do espaço de trabalho do pedagogo reverberou na constituição das identidades profissionais, já que em função da ausência de um detalhamento legal e das latas possibilidades de atuação, o sujeito se depara com barreiras para a formação de seus parâmetros, identificações e elaboração de teias relacionais que compõem os sentidos identitários. É percebido, portanto, a presença de um currículo nublado, penumbroso, que evidencia um desenvolvimento formativo questionável e inadequado. A situação do licenciado também se fazia análoga a do bacharel, em termos dos problemas na formação, pois de acordo com Silva (1999, p. 35) a precariedade da licenciatura se dava,

[...] pois não tinha o curso normal como um campo exclusivo de atuação. Isto porque a Lei Orgânica do Ensino Normal - o Decreto-Lei no 8.530/46 - estabelecia que, para lecionar nesse curso, era suficiente, em regra, o diploma de ensino superior. Enfim, prova de quão difuso era o mercado de trabalho do licenciado em Pedagogia foi o direito de lecionar Filosofia, História e Matemática a ele conferido.

Nessa direção, mesmo com a presença de um discurso desejoso pela profissionalização da docência, a atividade tanto em termos formativos quanto em regulatórios da inserção profissional, não eram denotados explicitamente. Assim, a formação em Pedagogia não assegurava aos egressos perspectivas bem definidas de futuro, já que não se definia os espaços e as funções desses 
profissionais. Logo, durante os anos de 1960, foram variadas as discussões acerca do curso, no sentido de reestruturá-lo ou até mesmo o tornar extinto. Tais pautas foram recorrentes no Conselho Federal de Educação (CFE), em pareceres e atas do relator Valnir Chagas. Um desses documentos foi o Parecer $n^{\circ} 251$ do ano de 1962, que discutia em razão da indefinição formativa e profissional, se o curso deveria deixar de existir ou ser remodelado. Entretanto, para Saviani (2012, p. 37) o Parecer não contribuiu com alterações significativas na ordem vigente, já que “A diferença fica por conta de certa flexibilidade, uma vez que as disciplinas de licenciatura poderiam ser cursadas concomitantemente com o bacharelado, não sendo necessário esperar o quarto ano”. Mesmo com a recusa do modelo do " $3+1$ ", as dicotomias forjadas nas separações de disciplinas e na falta de interlocução entre os elementos da teoria e da prática continuaram latentes. Embora, as instituições pudessem sistematizar os conteúdos atribuídos ao quarto ano de curso, a grade curricular continuava com poucas mudanças e com uma visão generalista da formação (SAVIANI, 2012). Ademais, Silva (1999, p. 37) afirma que

[...] é interessante observar que o referido parecer não identifica precisamente o profissional a que se refere; trata do assunto de maneira geral quando estabelece que o curso de Pedagogia destina-se à formação do "técnico de Educação" e do professor de disciplinas pedagógicas do curso normal, através do bacharelado e da licenciatura, respectivamente.

De forma contínua, a divisão entre conteúdos disciplinares e matérias que versam sobre métodos, continuam a representar um desafio do desenvolvimento profissional para o entendimento da profissionalização, tanto de licenciados quanto de bacharéis. Desse modo, apesar das discussões com relação a extinção ou a remodelação do curso, seu futuro e sua relevância social, a prática dos cursos e dos currículos, remontavam a década de 1940, uma vez que as poucas alterações empreendidas não foram suficientes para propor uma mudança significativa na ordem vigente. As questões relativas aos desafios do curso de Pedagogia movimentaram os cenários educacional e político durante os anos de 1960, como supracitado, mas em função do golpe que instaurou a ditadura civil-militar no Brasil em 1964, todos os debates acerca da formação docente e do ensino foram conduzidos a partir do olhar autoritário do regime de exceção. Nesse sentido, para Scheibe 
(2008, p. 45) o governo tomou medidas em prol do disciplinamento de discentes e docentes, além de propor medidas privatistas para o setor educacional, deixando explícito que

\begin{abstract}
Após a implantação do regime militar de 1964 e da Lei ${ }^{0} 5.692$, de 1971 o modelo de formação de professores foi em grande parte descaracterizado. Esta lei reformou o ensino obrigatório que passou a denominar-se de primeiro grau, estendendo-o de quatro para oito anos, juntando o primário ao ginásio; implantou também a profissionalização compulsória no ensino de segundo grau, transformando a escola normal numa das habilitações profissionais deste nível de ensino. Outra legislação deste período, a Lei n ${ }^{\circ} 5.540$, de 1968 que reformou o ensino superior, já trouxera modificações para o curso de pedagogia, fracionando em habilitações técnicas para a formação dos especialistas em educação. Permitia, no entanto, em decorrência da manutenção da habilitação para a docência no curso normal, que se habilitasse também o professor primário em nível superior, já então uma reivindicação dos educadores.
\end{abstract}

Scheibe (2008) faz uma síntese das principais transformações do período da ditadura civil-militar no campo educacional. Em relação ao curso e ao profissional de Pedagogia, se destacam o Parecer no 252 e a Resolução no 2 do CFE, ambas do anos de 1969, que contaram com a participação do conselheiro Valnir Chagas e que encaminhavam após a discussão do histórico e dos desafios do curso, um direcionamento que a Reforma Universitária seria o percurso a ser adotado. O que estava em pauta era que o curso de Pedagogia não deveria ser dividido em demais áreas, em razão da unicidade do sentido e do princípio educativos. Bastaria, então, definir limites e distinções no desenvolvimento da formação. Nesse sentido, constituiu-se um curso de estrutura comum, generalista e outro diversificada. No último, era o espaço de escolha entre as distintas habilitações que permeavam a profissionalização pedagógica, quais sejam: Supervisão, Inspeção, Orientação ou Administração Educacionais em escolas de primeiro e/ou segundo graus e Ensino para os Cursos Normais (SAVIANI, 2012). O objetivo da base diversificada na formação era romper com a formação generalista do curso de Pedagogia, formando técnicos especialistas em setores específicos para as demandas do mercado profissional. Desse modo, Silva (1999, p. 43) entende que

[...] num determinado momento do curso, os alunos passassem a fazer suas opções curriculares em função das tarefas que pretendessem desempenhar dentre as que se esboçavam e as que já se encontravam definidas para o pedagogo. Aliás, esta era uma tendência que se intensificava na área da educação em geral: a de se estabelecer a correspondência direta e imediata entre currículo e tarefas a serem desenvolvidas em cada profissão. 
Em um primeiro olhar, as mudanças pareciam satisfatórias e encaminhadas na direção da reformulação do curso que era necessária, bem como no atendimento das especificações de atribuições pedidas na inserção profissional e na dinâmica da lógica da estruturação do trabalho. Assim, imaginou-se que a mudança curricular seria bem-vinda, como forma de se especializar as diferentes funções que poderiam ser exercidas pelas pedagogas, a partir de uma articulação com a base comum, generalista. Porém, em razão da ausência de clareza com relação à caracterização e à identidade dos especialistas, bem como a posição periférica do Brasil na ordem do sistema capitalista internacional, fez com que o mercado nem mesmo desse conta de gerar a demanda por tantos e diferentes especialistas, como aponta Saviani (2012). Em decorrência disso, Silva (1999) retrata que ocorreu um excesso de oferta no setor educacional, gerando desemprego e o maior enfraquecimento das identidades profissionais, pois cada sujeito poderia ter mais de uma habilitação, embora a inserção profissional não acontecesse ou fosse morosa. Destarte, embora se apresentasse com ares de avanço e de mudança, a lógica da reestruturação do curso de Pedagogia, com a base diversificada de habilitações, se mostrou ineficaz quanto a superação das dicotomias histórias forjadas na graduação, tendo como produto o que Saviani $(2012$, p. 44) retrata como “[...] uma descaracterização e um esvaziamento ainda maior do curso".

Um dos principais desafios que se apontava era que as discussões educacionais estavam subservientes aos interesses do mercado. Nesse sentido, não compunham os debates as questões relativas ao desenvolvimento social, as desigualdades, a falta de acesso e de permanência as instituições escolares, mas sim, a dinâmica de privatização e de aumento dos lucros, eram preconizadas. A escola era entendida como espaço central para a formação de trabalhadores que contribuíram para a superação da própria carência, advinda dos problemas sociais, bem como motor para a retirada do país do atraso econômico histórico, quando comparado aos países que compunham a ordem capitalista internacional. Nessa direção, a escola e o ensino passam a ser encarados tais quais uma dinâmica fabril, que segundo Saviani (2013) se orientará pelo modelo tecnicista, que apregoa tal qual como mercado, os paradigmas de eficiência, produtividade e 
racionalidade na organização dos processos de ensino e de aprendizagem, no caso, com a finalidade de crescimento do sistema capitalista. A efetivação desse modelo durante a ditadura civil-militar, reverberou na formação de professores como meros tarefeiros, reprodutores de teorias e de paradigmas, além de explicitar o projeto do regime que era paralelo aos interesses privatistas para o campo educacional. Assim, portanto, forjou-se uma formação calcada na base tecnicista, que se pretendia neutra, afastada de toda implicação social e política, haja vista o período de exceção, de autoritarismo, de censura, de violência e de agravo das desigualdades sociais, que foram as marcas da ditadura civil-militar. Mota e Lopez (2016) ainda destacam que o contexto posterior ao da Segunda Guerra Mundial (1937-1945) traz à baila o debate sobre diversas vertentes do desenvolvimento socioeconômico, sendo a mais destacada a que defendia o Estado como promotor de tais políticas. Entretanto, os ecos das discussões que chegam ao Brasil durante o regime civil-militar não as recebem com bons olhos, devido ao alinhamento do governo com o setor privado e de seu compromisso com a expansão do capital. A postura governamental poderia ser observada nas reformas realizadas nos segmentos de ensino, a exemplo da universitária. Sobre ela, que se iniciou no ano de 1968, Chauí (2016, p. 63) afirmou que

[...] convertida em problema político e social prioritário, a universidade será reformada para erradicar a possibilidade de contestação interna e externa e para atender às demandas de ascensão e prestígio sociais de uma classe média que apoiara o golpe de 1964 e reclamava sua recompensa.

Assim, a tônica da Reforma Universitária, buscou modificar algumas relações formativas, com o objetivo de compor uma mão-de-obra mais especializada, respondendo aos anseios de adequação à lógica do capital, bem como para o atendimento de setores da classe média, apoiadores do golpe que desejavam mais status social. Nesse sentido, ocorre um aumento do oferecimento de vagas no ensino superior, mas como apontado anteriormente, a destinação possuía remetentes certos. Algumas mudanças geradas pela Reforma Universitária foram a departamentalização, a criação do ciclo, curso básico e a matrícula por disciplinas, que entre outras, baseadas sob a égide 
da eficiência e do controle, visava supervisionar e reduzir os investimentos públicos. Sobre a departamentalização, Chaú (2016, p. 64) afirma que

Consistiu em reunir num mesmo departamento todas as disciplinas afins, de modo a oferecer cursos num mesmo espaço (uma única sala de aula), com o menor gasto material (desde o giz e o apagador até mesas e carteiras) e sem aumentar o número de professores (um mesmo professor devendo ministrar um mesmo curso para maior número de alunos). Além de diminuir os gastos, a departamentalização facilita o controle administrativo e ideológico de professores e alunos.

As consequências geradas no âmbito universitário encaminharam para o enfraquecimento de laços entre a comunidade de estudantes, de professores e de demais sujeitos, uma vez que havia a formação de pequenos conglomerados de alunos que se fragmentava a cada semestre. Tal maquinação era intencional do regime civil-militar, pois foi uma forma eficiente de minar os vínculos com a formação que se tornava mais aligeirada e era uma maneira de exercício do controle e da punição a qualquer outro discurso desviante da norma, embora resistências variadas ocorressem. No tocante à formação de professores, Chauí $(2016$, p. 65) trata que foi sentido impacto destacado, já que

[...] as licenciaturas curtas em ciências, estudos sociais e comunicação e expressão permitem, a curto prazo, satisfazer a demanda crescente dos estudantes e mantê-los por pouco tempo nas escolas, diminuindo gastos, enquanto, a longo prazo, aumentando a oferta de mão de obra para os cursos do ensino médio, garantem a baixa remuneração do professorado desse nível de ensino.

Saviani (2008, p. 10) ainda assevera que, embora possa se entender que houve uma expansão dos sistemas de ensino durante o regime civil-militar, as desigualdades foram agravadas e “[...] o orçamento da União para educação e cultura caiu de 9,6\% em 1965, para 4,31\% em 1975”. Logo, reitera-se a compreensão que a educação era subserviente aos interesses do capital, já que a formação apontava para o fomento de uma massa de mão-de-obra que, em uma ínfima parte era mais especializada, sendo a maioria qualificada minimamente para os interesses da produtividade e do trabalho dócil ao mercado, em razão dos processos educativos não privilegiarem a reflexão, mas sim, o tecnicismo, calcado na ausência das discussões sociopolíticas e dos vínculos humanos. Destarte, as características das reformas educacionais realizadas pelo governo apontam para o apoio ao crescimento do capital e a aposta incerta da profissionalização precária e sua absorção pelo 
mercado. Diferentemente do que pode-se imaginar, o Estado teve forte presença no período, com intervenções alinhadas as ideias privatistas e de redução dos investimentos na pasta educacional. Com o golpe civil-militar, com as práticas autoritárias e com a prerrogativa da proteção da segurança nacional, o Estado selou sua subserviência ao privado, e para Saviani (2012, p. 45) desse modo

[...] a questão educativa é reduzida dominantemente à sua dimensão técnica, afastando-se o seu caráter de arte e secundarizando, também, as exigências de embasamento científico. Daí a pretensão de formar os especialistas em educação por meio de algumas poucas regras compendiadas externamente e transmitidas mecanicamente, articuladas com o treinamento para a sua aplicação no âmbito de funcionamento das escolas.

O quadro que se anuncia é a formação em massa de professores com apenas o nível médio para atuar nas escolas de primeiro grau, sem passarem por uma experiência universitária, um ensino aprofundado e reflexivo, generalista e distante do encontro com as práticas cotidianas. Portanto, as consequências para os professores formados dessa forma sinalizam para a precarização do trabalho docente, visto o enfraquecimento de sua profissionalização e das relações político-econômicas, o esfacelamento de suas identidades, em razão da formação aligeirada, da dicotomia forjada entre os elementos de teoria e de prática e a situação do mercado de trabalho, a desvalorização e a desumanização, quando se nega a possibilidade de reflexão e se instaura um modelo formativo tecnicista. Saviani (2012, p. 45) ainda destaca que por mais que as questões acerca da formação de professores não possam ser entendidas como mero jogo causal de consequências e que existam resistências e itinerários outros, o cenário é preocupante, uma vez “[...] que a escola já está devidamente organizada e o ensino funcionando dentro de parâmetros adequados, cabendo ao especialista inserir-se nela para garantir-lhe a eficiência por meio de uma racionalidade técnica que maximize a sua produtividade".

Uma das outras faces que reforçam a perversidade desse esquema formativo é o processo de responsabilização docente, que atua como forma do poder público se ausentar de suas responsabilidades e culpar o professor pelo fracasso da sua formação e do processo de ensino e de aprendizagem dos alunos, pretensamente atestados por avaliações externas e em longa escala. 
Assim, contribui-se com o círculo vicioso de não discussão e de não efetivação de melhores condições de trabalho, de remuneração, de planos de carreira e de oportunidades de formação continuada para os docentes. Desse modo, os professores são alvo de perseguições e se instaura um clima competitivo e não colaborativo entre os sujeitos do espaço escolar, o que só acarreta em prejuízo para as práticas e relações educativas. Mesmo nesse cenário, a formação docente não é revista, pois já se culpou ou responsabilizou os contextos, os alunos e os próprios educadores pelos denominados fracassos escolares. Assim, no período da ditadura civil-militar, sob as égides da segurança nacional, da coerção, da integração e do desenvolvimento, os problemas da escola não eram discutidos, por serem entendidos como elementos subversivos a ordem ideológica do governo e por, segundo Chauí (2016, p. 67) afirmar que

\begin{abstract}
A educação é fator primordial de desenvolvimento econômico da nação, afirma-se que, a longo prazo, ela beneficia igualmente a todos e que seu crescimento bruto é, em si e por si, índice de democratização. Afirmando-se que a educação é fator de integração nacional, afirma-se que ela racionaliza e unifica a vida social, moderniza a nação, gerando progresso que, a longo prazo, beneficia igualmente a todos. Como o desenvolvimento é nacional, a dimensão de classe da educação é anulada. Como a integração é nacional, a reprodução de relações de classe pela mediação da estrutura ocupacional definida pela escolarização também é ocultada.
\end{abstract}

Destarte, para além de ser subserviente aos interesses do capital, a educação foi arma ideológica que foi manipulada de modo a não discutir as questões sociais, de despolitizar os debates, de fomentar as desigualdades, de responsabilizar sujeitos frente a contextos estruturais e precedentes. É claro que frente a esse contexto, uma série de ações que representavam resistência à ordem vigente foram perpetradas, fazendo que ainda nos anos finais da década de 1970 o governo civil-militar demonstrasse seus primeiros sinais de esgotamento. É nesse ambiente de início da luta pela redemocratização do país, que Silva (1999) compreende que ocorre a emergência das discussões acerca do papel do pedagogo e do curso de Pedagogia, reivindicando uma formação lata, com centralidade nos aspectos da docência, que será pautada durante a deterioração da ditadura, por todo o processo de abertura política até o início da década de 1990. 
Antunes e Pinto (2017, p. 63) destacam que em função da crise do sistema capitalista da década de 1970, as relações entre o Estado e o mundo do trabalho mudariam, já que as alterações estatais visariam “[...] recuperar seu ciclo reprodutivo e, ao mesmo tempo, repor seu projeto de hegemonia, que fora então confrontado pelas lutas operárias". Assim, é sentido um contínuo de esvaziamento e de não responsabilização do Estado frente aos setores ligados aos direitos sociais, como educação e saúde, oferecendo espaço para a atuação do setor privado. De forma concomitante, Antunes e Pinto (2017, p. 64) observam a emergência do modelo toyotista na estrutura e gestão do trabalho que “[...] estabelece uma produção mais diretamente vinculada à demanda", uma vez que “[...] se estrutura no trabalho em equipe, rompendo com o caráter parcelar típico do fordismo, baseando-se num processo produtivo flexível onde o/ a trabalhador/a opera simultaneamente várias máquinas". A escola, então, passa a atuar como um instrumento da reprodução social, em meio de embates político-econômicos e ideológicos. É no espaço escolar que se formaria mão-de-obra nos moldes exigidos pelo mercado, contribuindo com o processo de expansão econômica do capital. Assim, imbuídos por uma lógica de flexibilização do trabalho e do ensino, bem como a priorização da noção produtivista, serão estimuladas perspectivas privatistas das políticas do Banco Mundial (BM) e do Fundo Monetário Internacional (FMI), que colocavam os empréstimos aos países subdesenvolvidos como uma moeda de troca para a adoção a tais medidas. Mota e Maués (2014) afirmaram que o paralelismo dos países periféricos aos programas do $\mathrm{BM}$ e aos pressupostos do FMI, representa uma adequação frente a mundialização e a financeirização econômicas. Para o campo educacional, as reformas se assentavam em três aspectos principais: avaliações externas e em larga escala, descentralização da gestão e foco no segmento de escolarização básica. Portanto, Mota e Maués (2014, p. 1.140) observam que

A descentralização da gestão em seus aspectos administrativos e financeiros significou a responsabilização crescente das instituições escolares pelo rendimento escolar de seus alunos, a partir de parâmetros de avaliação definidos externamente e maior racionalização nos gastos [...] E a centralização dos sistemas de avaliação como forma de fixar padrões de desempenho e induzir aos resultados esperados pelas escolas e pelos alunos. 
Não faz sentido propor, mesmo que apenas no campo discursivo, a autonomia da escola, e realizar em contrapartida a responsabilização dela e de seus agentes, sobretudo os professores, pelo desempenho aquém do esperado. O que ocorre na prática é uma política de formação de rankings das escolas, em razão das notas obtidas em avaliações externas e de larga escala e da instauração de uma noção de culpa e de competição por bônus salariais entre os professores, também em função dos resultados obtidos pelas turmas (BONAMINO; SOUSA, 2012). Logo, dentro de um quadro educacional precário, alinhado aos paradigmas do mercado relacionados a produtividade, desempenho individual e flexibilização, os professores e gestores são pressionados por metas e estatísticas das avaliações externas, explicitando os problemas da carreira e do trabalho, bem como, secundarizando o processo de formação humana e de ensino-aprendizagem dos alunos. Portanto, Libâneo (2016, p. 47) retrata que ao final

[...] a educação é a solução para prevenir problemas da expansão capitalista em decorrência da marginalidade e da pobreza. Daí que a aprendizagem e a escola se prestam, em primeira instância, à solução de problemas sociais e econômicos dentro dos critérios do mercado global. A satisfação de necessidades básicas de aprendizagem significa criar os insumos necessários para que o aluno alcance a aprendizagem como produto, ou seja, conhecimento e habilidades necessárias ao mercado de trabalho.

Os apontamentos de Libâneo serão as temáticas recorrentes na discussão da criação da Lei de Diretrizes e Bases da Educação Nacional (LDB), já nos anos finais da década de 1990. Além disso, é importante ressaltar que mesmo percorrendo mais de uma década do fim da ditadura civil-militar com o processo de abertura e participação política, a reestruturação da educação nacional ainda andava em passos tímidos, distante dos ideais da redemocratização, evidenciando as disputas e os jogos de interesse e poder que envolviam o campo. Tanto que, as bases que discorriam acerca da formação de professores continuaram praticamente as mesmas desde a década de 1970, valorizando o modelo tecnicista. Oliveira (2009) ainda destaca que compunha também esse cenário as políticas públicas antagônicas que queriam conciliar duas exigências excludentes: atender aos interesses do mercado e garantir o direito universal a educação, como presente na Constituição Federal de 1988. 
As Diretrizes Curriculares Nacionais para os Cursos de Graduação em Pedagogia (DCN’s) de 2006 impactaram e foram um dos orientadores da licenciatura, por representar um conjunto de esforços frente as discussões e os desafios acumulados nas últimas décadas, como a superação da falsa dicotomia forjada entre os elementos de teoria e de prática. As DCN's objetivavam a criação de currículos para o curso de Pedagogia, observando a interação entre as disciplinas e a atuação profissional futura. Entretanto, o documento ficou distante de ser um ponto pacífico entre os especialistas. Para Scheibe (2007) as diretrizes não foram construídas levando em consideração os avanços teóricos e acadêmicos do campo e continuaram a investir em disposições curriculares amplas. Libâneo (2010) na mesma direção, também afirma que as DCN's não contribuíram significativamente com a constituição das identidades docentes, por ter caráter contraditório e provisório. Scheibe (2007) dispõe que os pareceres e os documentos enfocaram a formação do licenciado em Pedagogia, fazendo uma distinção com o pedagogo, que será discutido a posteriori.

Perante a miríade de questões que se colocavam diante das incongruências das diretrizes e da amplitude de inserção profissional, o pedagogo e o licenciado em Pedagogia se colocaram de maneira incerta e confusa. Libâneo (2010, p. 46) aponta que desde a década de 1980 entidades como a Associação Nacional pela Formação dos Profissionais da Educação (ANFOPE) se manifesta em prol da reformulação curricular dos cursos de licenciatura, reafirmando "a ideia de que o curso de Pedagogia é uma licenciatura, contribuindo para descaracterizar a formação do pedagogo stricto sensu". Logo, as condições de trabalho e a profissionalização dos pedagogos eram temas discutidos pelos profissionais da educação, aproveitando o ambiente de redemocratização e contestação as premissas do regime civil-militar. É nessa direção que se rende críticas as estruturações das instituições escolares, por reproduzirem a lógica de produção e da divisão de trabalho do sistema capitalista, visando formar profissionais minimamente capacitados e obedientes as hierarquias do capital. Libâneo (2010) portanto, marca que as críticas questionavam a escola como garantidora do status quo do capital, desvalorizando o papel do docente e do pedagogo. 
Libâneo (2010) comenta que pôr a escola seguir uma lógica de organização tal qual da fábrica e da produção, a comunicação entre os próprios docentes e entre os demais profissionais que atuavam na gestão, na supervisão ou na orientação, foi minada e reduzida ao cumprimento de normas e cartilhas. Por terem formações distintas e muitas vezes estruturadas na dicotomia entre teoria e prática e na falta de interlocução com o espaço escolar, fomentava-se um quadro de clivagem no interior da escola, que segregava o funcionamento escolar e impactava negativamente o processo de ensino e de aprendizagem. Ao invés de se apostar em uma visão conectada e integral do espaço e das dinâmicas formativas, continuava-se a pensar na lógica fragmentada e ineficiente das diferentes habilitações, gerando, desse modo, um debate sobre o fim das "[...] habilitações convencionais (administração escolar, orientação educacional, supervisão escolar etc.), para investir num currículo centrado na formação de professores para as séries iniciais do ensino fundamental e curso de magistério.” (LIBÂNEO, 2010, p. 46).

Diante do exposto, é nítido observar dois pontos: a perspectiva de uma escola dual (BAUDELOT; ESTABLET, 1971), cabendo a instituição que recebia o público de camadas populares, a formação de trabalhadores dóceis, que não questionassem o quadro de desigualdades que estavam inseridos, já que o desenvolvimento do país dependia do trabalho e do consumo desses trabalhadores. Refletir ou indagar se configurava como uma medida de tentativa de ruptura as lógicas hierárquicas que eram apensadas tanto na fábrica, como na escola. Para Libâneo (2010), tal configuração da escola se devia as marcas do autoritarismo da ditadura, além do explícito alinhamento aos interesses do capital. É no período dos anos 1980, como fora supracitado, que ganhou força um levante dos profissionais da educação e da comunidade escolar em prol de formações e configurações mais equitativas, democráticas e participativas, observando as condições de trabalho e o processo de ensino e de aprendizagem. Entretanto, os mais de vinte anos das recentes lutas e críticas em relação à escola e à formação docente, não foram contempladas nas DCN's de 2006, como indicado anteriormente, já que o documento insistia na perspectiva de segregar por habilitações e funções, fragmentando o processo educativo e as identidades 
profissionais. O Parecer n ${ }^{\circ} 5$ de 2005 do Conselho Nacional de Educação (CNE) (BRASIL, 2005, p.

10) endossa tal perspectiva já que

Sendo a docência a base da formação oferecida, os seus egressos recebem o grau de Licenciados(as) em Pedagogia, com o qual fazem jus a atuar como docentes na Educação Infantil, nos anos iniciais do Ensino Fundamental e em disciplinas pedagógicas dos cursos de nível médio, na modalidade Normal e de Educação Profissional na área de serviços e apoio escolar e em outras em que disciplinas pedagógicas estejam previstas, no planejamento, execução e avaliação de programas e projetos pedagógicos em sistemas e unidades de ensino, e em ambientes não escolares.

O cenário que se apresenta é o de variadas e idiossincráticas funções atribuídas a um único trabalhador, o pedagogo. Mesmo com as extinções das habilitações, de uma formação integral e dialógica e da tentativa de uma estruturação democrática das escolas, algumas perguntas acerca das identidades persistiam: O que é o pedagogo profissionalmente? Para que o pedagogo foi formado? O processo formativo do pedagogo o habilitaria para que ele tivesse desenvolvimento específico para atuar em áreas diversas? O pedagogo pode exercer outras funções que não as relacionadas ao ensino? Assim, a figura multifacetada do pedagogo estava presente desde as pré-escolas, as instituições de ensino fundamental no primeiro segmento, no ensino médio quando fosse uma Escola Normal, ou mesmo em outras atribuições como coordenador pedagógico, supervisor escolar ou orientador, a depender da nomenclatura, além de outros espaços, como os não-formais. Portanto, observa-se que o ponto basilar da formação do pedagogo é a docência e são os conhecimentos pedagógicos os norteadores para a prática relacional e educativa democráticas.

Cabe ressaltar que os questionamentos expostos acima sintetizam a tônica das críticas ao texto das DCN's, em função da atribuição de um papel genérico ao pedagogo, para além da docência, tentando deslegitimar ou enfraquecer o campo pedagógico como científico, em razão das distintas vertentes, às vezes não paralelas acerca dos temas. Contudo, a ciência não se restringe a uma visão complementar, mas sim global de conhecimentos. Nesse sentido, Libâneo (2010, p. 54) afirma que deve ser enfocada "[...] a peculiaridade da Pedagogia de responsabilizar-se pela reflexão problematizadora e unificadora dos problemas educativos, para além dos aportes parcializados das demais ciências da educação". Portanto, não se deve minorar o conhecimento pedagógico o 
limitando aos aspectos do ensino, uma vez que tais aspectos não conseguem abarcar os inúmeros fatores e contextos que se intercruzam as práticas educativas. Dessa forma, é necessário unir a discussão, considerando as faces de docente e de pesquisador da Pedagogia contida nos sujeitos, explicitando o compromisso crítico, ético e social com a profissão, com os conhecimentos produzidos e com os interlocutores, mostrando que a docência supera a aplicação ou a reprodução de métodos e técnicas. Logo, o próprio Parecer $n^{\circ} 5$ do CNE (BRASIL, 2005, p. 6), já retratado no artigo, concorda com a consideração da junção do professor e do investigador e da necessidade de uma formação consolidada, já que

\begin{abstract}
A educação do licenciado em Pedagogia deve, pois, propiciar, por meio de investigação, reflexão crítica e experiência de planejamento, execução, avaliação de atividades educacionais, a aplicação de contribuições de campos de conhecimentos, como o filosófico, o histórico, o antropológico, o ambiental-ecológico, o psicológico, o linguístico, o sociológico, o político, o econômico, o cultural. O propósito dos estudos destes campos é nortear a observação, análise, execução e avaliação do ato docente e de suas repercussões ou não em aprendizagens, bem como orientar práticas de gestão de processos educativos escolares e não-escolares, além da organização, funcionamento e avaliação de sistemas e de estabelecimentos de ensino.
\end{abstract}

Não é viável pensar que a formação inicial fosse o espaço mais adequado para propor uma atividade formativa tão extensa e ampliada como a empreendida pelo curso de Pedagogia. Ademais, como já pontuado, pulverizar habilitações enfraquece o desenvolvimento formativo como um todo, inclusive a docência, atividade base da profissão. A partir desse ponto e da centralidade do ensino, como formar pedagogos para atuar nos diversos ramos de conhecimento, sejam eles nas atividades ligadas a gestão ou as relacionadas a educação infantil, alfabetização e mediação nas demais disciplinas presentes no ensino fundamental I? Que tipo de formação deveria ser preconizada? Uma mais global ou mais específica para cada área do conhecimento? Como encaminhar a formação do pedagogo de forma a relacionar as disciplinas e os componentes e espaços práticos da atuação profissional cotidiana? Como formar pedagogos para a construção de relações escolares mais comunicativas e mais democráticas? Distante e sem pretensão de oferecer respostas conclusivas aos anseios e as questões, conseguimos refletir que após de mais de uma década da publicação das DCN's e uma série de mudanças nos cotidianos sociais, políticos, econômicos e históricos, um 
outro questionamento que se avulta, frente a construção de conhecimentos é se a formação pedagógica foi preconizada ou não a partir das novas diretrizes para os cursos de licenciatura?

A produção acerca das DCN's, da formação de professores, dos cursos de Pedagogia e de outros aspectos legais que envolvem os temas são vastos no Brasil. Entretanto, embora as idiossincrasias de cada curso e de cada foco das produções, em linhas gerais, as investigações demonstram currículos fragmentados e disciplinas desconectadas, como apontam Gatti et. al. (2019) e Fenelon (2008). Para Pimenta et. al. (2017, p. 22) ocorrem “[...] uma grande quantidade e diversidade de disciplinas oferecidas pelos cursos investigados, muitas delas sem aderência à docência e às questões próprias dos anos iniciais da educação básica. Isso sugere um perfil amplo, disperso e impreciso do egresso dos cursos analisados [...]". Nessa mesma perspectiva, o que é percebido que partindo de uma organização curricular desconectada, os saberes e os conhecimentos acessados e produzidos na fase inicial de formação não encontram solo fértil para se efetivarem ou dialogarem com as práticas cotidianas. Assim, para Pimenta et. al. (2017, p. 24) acaba por ocorrer uma “[...] difusão e dispersão na formação do pedagogo, o que acaba por inviabilizar uma sólida formação de professor polivalente para os anos iniciais do ensino fundamental e da educação infantil”. Gatti (2012, p. 258) aponta que no sentido de refletir mais sobre o tema, as licenciaturas em geral, mas com o recorte específico para a Pedagogia, os cursos carecem de disciplinas que tratem do ensino, “[...] como a pouca incorporação de aspectos relativos à Didática e às Práticas de Alfabetização, às práticas relativas ao ensino de outras disciplinas dos primeiros anos do Ensino Fundamental, e as associadas à Educação Infantil”. A autora continua analisando e compreende que é destinado um tempo reduzido para as atividades relativas às linguagens, suas práticas e suas didáticas, reverberando incisivamente no cotidiano dos professores do ensino fundamental I, por exemplo. Na pesquisa de Pimenta et. al (2017, p. 22), dentre os 125 cursos de Pedagogia de instituições privadas e 19 de universidades públicas, no estado de São Paulo, pode-se entender que, em relação a carga horária, menos de quarenta por cento das graduações 
[...] contempla disciplinas relacionadas aos conteúdos curriculares (língua portuguesa, matemática, história, geografia, ciências, artes, educação física, alfabetização, movimento, linguagem oral e escrita, natureza e sociedade, por exemplo), normalmente vinculados às suas respectivas metodologias de ensino, assim como outros conteúdos relacionados com a prática docente na educação infantil e nos anos iniciais de escolarização.

Por isso da insistência na defesa de uma formação sólida e consolidada para os professores, uma vez que, como os pedagogos necessitam ensinar conteúdos de áreas distinta, precisa de um conhecimento teórico e metodológico ampliado, sem perder a interface com os contextos de atuação. Nesse sentido, as Diretrizes Curriculares (BRASIL, 2006, p. 3) indicam a formação de núcleos para os estudos considerados basilares para que ocorra a

decodificação e utilização de códigos de diferentes linguagens utilizadas por crianças, além do trabalho didático com conteúdos, pertinentes aos primeiros anos de escolarização, relativos à Língua Portuguesa, Matemática, Ciências, História e Geografia, Artes e Educação Física.

O pedagogo portanto, deve ter uma formação sólida para as teorias e metodologias próprias de cada disciplina, trabalhando conforme as diretrizes (BRASIL, 2006, p. 2) “[...] de forma interdisciplinar e adequada às diferentes fases do desenvolvimento humano". O presente texto acaba por oferecer destaque na atuação em docência no ensino fundamental I, mas sem desconsiderar que existem tantas outras particularidades na educação infantil ou na supervisão e coordenação escolares, revelando as exigências variadas e o leque de possibilidade de atuação. Desse modo, questiona-se: Os professores especializados em um ramo do conhecimento já enfrentam uma série de desafios para ensinar, o que pensar de um pedagogo que possui uma atuação polivalente? Como ele estuda, adequa e relaciona todas as matérias na mediação do processo de ensino e de aprendizagem? Como apontado em investigações supracitadas, a questão fica mais sensível quando se observa que as disciplinas das outras áreas do conhecimento são em carga horária reduzida ou enfáticas nas metodologias para se ensinar. Destarte, observando o quadro, entende-se que a formação específica em um campo disciplinar já é uma atividade emblemática, que fica muito mais complexa quando se exige do pedagogo um domínio das diversas matérias, quando se oferece uma graduação generalista, reduzida e difusa. 
Saviani (2005, p. 13) observa que ao pedagogo, como ao licenciado de modo geral, além do conhecimento metodológico para se ensinar, é necessária uma compreensão vasta e sólida das relações disciplinares com o cotidiano social da escola, reconhecendo os avanços e as produções científicas acumuladas ao longo da história da humanidade, entendendo “[...] o trabalho educativo é o ato de produzir, direta e intencionalmente, em cada indivíduo singular, a humanidade que é produzida histórica e coletivamente pelo conjunto dos homens.”. Logo, embora existam as relações com os cotidianos sociais e com os saberes tácitos da profissão, a docência tem como base os princípios dos conhecimentos científicos e sistematizados, marcando uma posição que se distancia de um ideal de dom, de missão e de vocação, evocando a preponderância da necessidade formativa e profissional. Assim, Saviani (2005, p. 15) escreve que:

\begin{abstract}
A escola existe, pois, para propiciar a aquisição dos instrumentos que possibilitam o acesso ao saber elaborado (ciência), bem como o próprio acesso aos rudimentos desse saber. As atividades da escola básica devem organizar-se a partir dessa questão. Se chamarmos isso de currículo, poderemos então afirmar que é a partir do saber sistematizado que se estrutura o currículo da escola elementar. Ora, o saber sistematizado, a cultura erudita, é uma cultura letrada. Daí que a primeira exigência para o acesso a esse tipo de saber seja aprender a ler e escrever. Além disso, é preciso conhecer também a linguagem dos números, a linguagem da natureza e a linguagem da sociedade. Está aí o conteúdo fundamental da escola elementar: ler, escrever, contar, os rudimentos das ciências naturais e das ciências sociais (história e geografia humanas).
\end{abstract}

O professor deve portanto, sistematizar suas práticas a partir dos conhecimentos sistematizados e chancelados pela academia e pelos contextos de atuação, tendo o pedagogo tarefa mais desafiante, em função da polivalência e dos conhecimentos fronteiriços com que ele se relaciona. Assim, mais uma questão se coloca no horizonte: Como as políticas públicas e a exemplo das DCN's, colaboram com a formação e atuação interdisciplinar dos docentes? A pergunta se torna mais desafiante quando observamos que a educação é tida como um privilégio para uma escassa elite que elabora propriamente as diretrizes e os currículos para si mesma. Apesar das discussões nos mais diversos momentos históricos, Saviani (2005) aponta que nunca fora efetivado um sistema educacional nacional, fato que reforçou e colaborou com a reprodução das desigualdades sociais e escolares, atingindo o grupo historicamente mais afetado, o das camadas populares. Embora as incongruências, o Parecer $n^{0} 5$ de 2005 (BRASIL, 2005, p. 5) que fundamenta as DCN's, já 
demarca a necessidade da compreensão das condições objetivas de vida e de existência, quando pontua que:

O projeto pedagógico do curso de Pedagogia deverá contemplar fundamentalmente: a compreensão dos processos de formação humana e das lutas históricas nas quais se incluem as dos professores, por meio de movimentos sociais; a produção teórica, da organização do trabalho pedagógico; a produção e divulgação de conhecimentos na área de educação que instigue o Licenciado em Pedagogia a assumir compromisso social.

Na mesma direção, o Parecer (BRASIL, 2005, p. 7) continua afirmando que o pedagogo, independentemente da posição que ele ocupe, não deve se manter distante dos agentes e contextos sociais, firmando uma posição contrária as desigualdades. Assim, o documento afirma, por exemplo que:

[...] a docência, tanto em processos educativos escolares como não-escolares, não se confunde com a utilização de métodos e técnicas pretensamente pedagógicos, descolados de realidade históricas específicas. Constitui-se na confluência de conhecimentos oriundos de diferentes tradições culturais e das ciências, bem como de valores, posturas e atitudes éticas, de manifestações estéticas, lúdicas, laborais.

Destarte, ademais do compromisso ético e social que assume perante seus interlocutores e com a profissão, o pedagogo em razão da natureza polivalente da sua atuação, deve observar as particularidades de cada área formativa, relacionando-as entre si e reendossando a postura em prol da construção justa e democrática de conhecimentos. Nesse sentido, o Parecer $n^{\circ} 5$ (BRASIL, 2005, p. 10) retrata que:

[...] a formação de professores, nas suas fases inicial e continuada, contemple a educação dos cidadãos(ãs), tendo em vista uma ação norteada pela ética, justiça, dialogicidade, respeito mútuo, solidariedade, tolerância, reconhecimento da diversidade, valorização das diferentes culturas, e suas repercussões na vida social, de modo particular nas escolas, dando-se especial atenção à educação das relações de gênero, das relações étnico-raciais, à educação sexual, à preservação do meio ambiente articuladamente à da saúde e da vida, além de outras questões de relevância local, regional, nacional e até mesmo internacional.

Entretanto, é relevante que se reflita se os pressupostos que dão base aos documentos legais refletem ou ecoam nas dinâmicas formativas e escolares, ou se não deitam raízes, permanecendo nas letras frias das legislações. Tanto Pimenta et. al. (2017) e Gatti (2012) apontam ser necessárias mudanças na estrutura formativa dos cursos de Pedagogia, uma vez que os currículos se assentam fragmentados e voltados aos interesses do mercado, com o oferecimento predominante em instituições privadas, de qualidade duvidosa, com graduações aligeiradas, sem oportunidades de 
pesquisa em estrutura física e de pessoal. Gatti $(2017$, p. 726$)$ ainda destaca a falta de interconexões entre as disciplinas dos distintos campos do conhecimento, o que retoma a um quadro amplamente criticado desde as primeiras décadas do século XX no Brasil, mantendo,

[...] uma estrutura formativa reificada nas proposições consolidadas entre nós, mais formalmente, nos inícios do século vinte, sem integrar a visão de que esses cursos objetivam formar profissionais para a educação escolar com as novas gerações, as licenciaturas se mostram em suas dinâmicas formativas alienadas das realidades socioculturais contemporâneas, da complexidade que transita do social para os espaços das escolas e das salas de aula, e das demandas que se colocam ao trabalho de um professor na interface com seus alunos no dia a dia das redes escolares.

Contudo, ocorrem ruídos e descompassos entre o que é apregoado e chancelado pelas legislações e pesquisadores, com o que é praticado nos cursos de formação e nas práticas pedagógicas. Uma ilustração disso é que as DCN's (BRASIL, 2006, p. 2-3) pregam em seu artigo quinto que o profissional da Pedagogia deve ser habilitado para:

I - atuar com ética e compromisso com vistas à construção de uma sociedade justa, equânime, igualitária;

$[\ldots]$

IX - identificar problemas socioculturais e educacionais com postura investigativa, integrativa e propositiva em face de realidades complexas, com vistas a contribuir para superação de exclusões sociais, étnico-raciais, econômicas, culturais, religiosas, políticas e outras;

$\mathrm{X}$ - demonstrar consciência da diversidade, respeitando as diferenças de natureza ambiental-ecológica, étnico-racial, de gêneros, faixas geracionais, classes sociais, religiões, necessidades especiais, escolhas sexuais, entre outras;

$[\ldots]$

XIV - realizar pesquisas que proporcionem conhecimentos, entre outros: sobre alunos e alunas e a realidade sociocultural em que estes desenvolvem suas experiências não-escolares; sobre processos de ensinar e aprender, em diferentes meios ambiental-ecológicos; sobre propostas curriculares; e organização do trabalho educativo e práticas pedagógicas;

Gatti (2010) aponta que, embora as recomendações, continua a se formar um profissional fragmentado, apartado das experiências de pesquisa em muitas vezes e distante das conexões entre as disciplinas que aprende e que ensina. Apesar de existirem tantos outros casos bem sucedidos e de cursos mais integrados, de modo geral, em função da estruturação das graduações e de estigmas históricos, a Pedagogia e os pedagogos permanecem minorados socialmente.

Ainda é importante ressaltar que somado a esse contexto é observado uma oferta expandida de cursos na modalidade a distância de graduação, muito deles privados, sem atividades presenciais, o que corrobora com os interesses do capital e enfraquece e/ou dificulta uma formação sólida, 
aproximada da pesquisa científica e relacional. Segundo Neto (2020) a oferta dos cursos de Pedagogia na modalidade de ensino a distância (EAD) chega a setenta por cento, com perspectivas de crescimento contínuo. Na crítica a esse tipo de formação, Gatti (2012, p. 163-164) dispõe que:

Esses professores trabalharão com crianças em tenra idade e com a alfabetização, trabalho que exige uma formação delicada, um aprendizado de relações pessoais, pedagógicas, didáticas, motivacionais e de formas de linguagem e comunicação específicas. A modalidade a distância não favorece esse tipo de formação. Não podemos apenas nos pautar por uma racionalidade técnica, como parece fazer o pensamento dominante nas políticas de formação docente.

É necessário entender que a demanda pelo EAD e seu crescimento vultuoso se deve também a necessidade por professores, observando um processo de massificação da escolarização ocorrido e ampliado entre os séculos XX e XXI. Entretanto, chama-se atenção que, para além das dificuldades de concretização do processo de expansão das instituições escolares e da obrigatoriedade no aumento dos anos cursados, tal dinâmica ficou distante de preconizar a qualidade da oferta, da permanência, do trabalho e da formação dos profissionais, sinalizando a continuidade do modelo fragmentado, apartado da pesquisa e sem conexões entre as disciplinas e os cotidianos de atuação.

Gatti (2012) ainda sinaliza que, de modo geral, existe um movimento de queda de matrícula em cursos de licenciaturas, tendo como hipóteses centrais o desprestígio social, a falta de reconhecimento e as condições precárias de trabalho e de remuneração. Acrescidos a isso, a autora em pesquisas no ano de 2010, também refletindo sobre variadas graduações na modalidade de licenciatura, apontou que grande parte são oferecidas em instituições privadas, obedecendo ao esquema supracitado que favorece aos interesses mercadológicos, tendo como público principal estudantes de camada popular, oriundos de escolas públicas e que tem no ensino noturno uma possibilidade de prosseguir nos estudos, haja vista que muitos necessitam de trabalhar para complementar a renda familiar. Gatti (2010) ainda ressalta que, apesar da profissão docente não ser valorizada e reconhecida socialmente, ela representa para o grupo que cursa as licenciaturas uma progressão social, o ingresso da primeira geração familiar no ensino superior e o horizonte da estabilidade empregatícia, frente à situações mais dramáticas de grande parte da população brasileira. 


\section{À GUISA DE CONSIDERAÇÕES FINAIS}

As perguntas realizadas ao longo do artigo se mostraram interessantes para problematizar a formação de professores à luz dos documentos legais, dos cursos de formação e das práticas profissionais em interface. A discussão também é justificada em função dos problemas de identidade desses licenciados em Pedagogia e do caráter único que tal curso de graduação possui, não encontrando padrão de analogia nos demais países, segundo Gatti (2012). O pedagogo tem como atividade central a docência, contudo sua formação assentada muitas vezes em um caráter generalista, fragmentado e com ausência de interconexões com as práticas cotidianas, faz com que ele tenha uma formação aquém da atividade realizada em sala de aula, bem como das demais funções que pode ocupar na estrutura escolar.

Com uma organização curricular que minora as demais disciplinas de outros campos específicos e que não dialoga com as inserções profissionais, a capacidade de reflexão fica prejudicada, fazendo com que não ocorra uma crítica e um intercâmbio entre as práticas e os conhecimentos produzidos. Nesse sentido, persistem as práticas historicamente criticadas e a manutenção da ausência de formação de um cabedal teórico consolidado, que permitem a continuidade de práticas tidas como questionáveis e campo possível para a reprodução das desigualdades.

Desse modo, revisitar de forma crítica a formação de professores e do pedagogo em especial, além de contribuir com a constituição das identidades impactaria o próprio quadro da educação nacional, já que entendendo o professor como um intelectual, ele estaria mais preparado para enfrentar e combater os desafios e as incongruências presentes na formação e na legislação, em prol de uma atuação comprometida com a justiça social. Destarte, sendo a atividade docente o pilar central da ação do pedagogo, se faz necessário refletir acerca da sua formação para que, ciente das 
novidades, das alteridades e do contexto de mudanças constantes, sua atuação possa refletir o atendimento frente as demandas complexas e o dialogismo entre as relações e as disciplinas.

\section{REFERÊNCIAS}

ANTUNES, Ricardo; PINTO, Geraldo Augusto. A fábrica da educação: da especialização taylorista à flexibilização toyotista. São Paulo: Cortez, 2017.

BAUDELOT, Christian; ESTABLET, Roger. L'ecole capitaliste en France. Paris, Maspero, 1971.

BONAMINO, Alicia; SOUSA, Sandra Zákia. Três gerações de avaliação da educação básica no Brasil: interfaces com o currículo da/na escola. Educação e Pesquisa, São Paulo, v. 38, n. 2, p. 373-388, abr./jun. 2012.

BRASIL. Conselho Nacional de Educação. Parecer CNE/CP 5, 13.12.2005. Brasília, 2005.

BRASIL. Resolução n.1, 15.5.2006. Diário Oficial da União, n.92, seção 1, p.11- 12, 16 maio 2006.

BOURDIEU, Pierre. O campo científico. In: ORTIZ, Renato (Org.). Pierre Bourdieu: sociologia. São Paulo: Ática, 1983a. p. 122-55.

BOURDIEU, Pierre. Questões de sociologia. Rio de Janeiro: Marco Zero, 1983b.

BOURDIEU, Pierre. Coisas ditas. São Paulo: Brasiliense, 1990.

CHAUÍ, Marilena. Ventos do progresso: a universidade administrada. In: ROCHA, André (Org.). A ideologia da competência. Belo Horizonte: Editora Autêntica; São Paulo: Editora Fundação Perseu Abramo, 2016.

FENELON, Déa Ribeiro. A formação do profissional de História e a realidade do ensino. Tempos Históricos, v. 12, p. 23-35, $1^{\circ}$ semestre 2008.

GATTI, Bernardete A. Formação de professores no Brasil: características e problemas. Educ. Soc., Campinas, v. 31, n. 113, p. 1355-1379, out.-dez. 2010.

GATTI, Bernardete A. Formação inicial de professores para a Educação Básica: pesquisas e políticas educacionais. Est. Aval. Educ., São Paulo, v. 25, n. 57, p. 24-54, jan./abr. 2014.

GATTI, Bernardete A. Formação de professores, complexidade e trabalho docente. Rev. Diálogo Educ., Curitiba, v. 17, n. 53, p. 721-737, 2017.

GATTI, Bernadete A.; BARRETO, Elba S. de Sá; ANDRÉ, Marli E. D. A. de; ALMEIDA, Patrícia C. A. de. Professores do Brasil: Novos cenários de formação. Brasília: UNESCO, 2019.

LIBÂNEO, José Carlos. Pedagogia e pedagogos, para quê? 12ª ed. São Paulo: Cortez, 2010.

LIBÂNEO, José Carlos. Políticas educacionais no Brasil: desfiguramento da escola e do conhecimento escolar. Cadernos de Pesquisa. V. 45, nº 159, p. 38-62, jan./ mar. 2016. 
MOTA, Carlos Guilherme; LOPEZ, Adriana. História do Brasil: uma interpretação. $5^{\mathrm{a}}$ ed. São Paulo: Editora 34, 2016.

MOTA JÚNIOR, William Pessoa; MAUÉS, Olgaíses Cabral. O Banco Mundial e as Políticas Educacionais Brasileiras. Educação \& Realidade. Porto Alegre, v. 39, no 4, p. 1137-1152, out./ dez. 2014.

NARITA, Felipe Ziotti. A educação da sociedade imperial: moral, religião e forma social na modernidade oitocentista. Curitiba: Editora Appris, 2019.

NETO, Sidney M. O ensino de História nos anos iniciais do ensino fundamental: entre práticas e problemáticas. Porto Alegre: Editora Fi, 2020. 175p.

PIMENTA, Selma Garrido; FUSARI, José Cerchi; PEDROSO, Cristina Cinto Araújo; PINTO, Umberto de Andrade. Os cursos de licenciatura em pedagogia: fragilidades na formação inicial do professor polivalente. Educação e Pesquisa, São Paulo,v. 43, n. 1, p.15-30, jan./mar. 2017.

SAVIANI, Dermeval. Pedagogia histórico-crítica: primeiras aproximações. $9^{\mathrm{a}}$ ed. Campinas: Autores Associados, 2005.

SAVIANI, Dermeval. Política educacional brasileira: limites e perspectivas. Revista de Educação PUC - Campinas. Campinas, $n^{0}$ 24, p. 7-16, junho 2008.

SAVIANI, Dermeval. Formação de professores: aspectos históricos e teóricos do problema no contexto brasileiro. Revista Brasileira de Educação. V. 14, nº 40, jan./ abr. 2009.

SAVIANI, Dermeval. A pedagogia no Brasil: história e teoria. $2^{\text {a }}$ ed. Campinas: Autores Associados, 2012.

SAVIANI, Dermeval. História das ideias pedagógicas no Brasil. Campinas: Autores Associados, 2013.

SCHEIBE, Leda. Diretrizes curriculares para o curso de pedagogia: trajetória longa e inconclusa. Cadernos de Pesquisa, v. 37, n. 130, jan./abr. 2007.

SILVA, Carmem Silvia Bissoli. Curso de Pedagogia no Brasil: História e Identidade. Campinas: Autores Associados, 1999.

TANURI, Leonor Maria. História da formação de professores. Revista Brasileira de Educação. $\mathrm{N}^{\mathrm{o}}$ 14, p. 61-88, 2000. 